\title{
ISLAMIC EDUCATION LEADERSHIP IN CONFLICT STATE: CASE STUDY IN SOUTHERN THAILAND
}

\author{
Lailiyatul Azizah \\ Universitas Islam Negeri Maulana Malik Ibrahim Malang, Indonesia \\ azizahlailiyatul@gmail.com
}

\begin{abstract}
This study aims to explore the practice of Islamic education leadership in the conflict state, in Pattani Southern Thailand, a region where the conflict is prolonged until the decades are between the Malay Muslim minority with the Thai government that is Buddhist. Using a qualitative approach with the method of case study, this study focused on Madrasah Pattani, with the head of madrasa, one teacher, and three alumni as informants. Interviews were conducted with FGD to find out the extent of leadership in Pattani Madrasas during the conflict. The results were found that in hard conditions, the madrasa could develop a strong madrasa vision by adopting a modern curriculum and integrate it with the Islamic curriculum of Islam. Although this method has been opposed to the entry of Buddhist teachers, the head of madrasah neutralise by making several activities to create social cohesion and build cooperation with universities abroad. Leadership mode is rare and difficult to implement in areas that are being hit by an ethno-political conflict on behalf of religion.
\end{abstract}

Keywords: Islamic education, leadership, South Thailand, madrasa, conflict.

\section{INTRODUCTION}

Leadership is the key to the success of a system in educational institutions (Ceallaigh \& Shéaghdha, 2021; Garza, Jr dkk., 2014; Gurr \& Drysdale, 2018). There is a strong relationship between the success of the school managing education with leadership factors that maximise existing resources for school progress (Seyfarth, 2002; Wößmann, 2003). Leadership did not turn up, but he was influenced by the contextual condition that fell. As Fiedler said, effective leadership came from the context of the conditions surrounding the school and its leader (Fiedler, 1967). 
This article explores the leadership of Islamic-based schools in Southern Thailand where the area is an ethno-political genre conflict area that occurs between Malay Muslim separatist movements against the Buddhist Thai government that lasts long ago. This dispute caused sublimation effects on social conditions in southern Thailand, especially the isolated and minority Muslims (Forbes, 1953; Man, 1985; Suhrke, 1977). Several studies have been carried out on school leadership in the conflict area (Brooks \& Brooks, 2019), but the focus of research in the school context as a nursery and custody preservation of ethnic-religious ideology is relatively rare (Liow, 2010; Liow \& Raya, 2020). Malay Muslims see the inequality given by the government towards madrasas to fund and some policies that discredit Muslim minorities in southern Thailand where the Buddhist empire dominates the government's policy assimilation. So that some Islamic schools and madrasas must open themselves in policy negotiations to their schools with the government, so school leadership is needed to survive in conditions.

The ethnic conflict that occurs in Southern Thailand threatens the development of Islamic education and school leaders get a kind of obstacle, among others: First, attacks from two camps (separatist rebels and governments) followed by various kinds of destruction and incidents of shootings that threaten to the people living in the region South (Harish, 2006; Yusuf, 2007). Some information got from one informant in this study he heard from relatives in southern Thailand that the attack also regarding school teachers, which according to the government's stronghold there were many groups of teachers who entered the ideology that supported the rebellion (Jerryson, 2009). Even a school teacher who teaches Islam must be interrogated because he once attended an event allegedly according to the Buddhist group was a seminar for a rebellion. School leaders in several Islamic schools in Southern Thailand must be truly careful in acting where Islamic school leaders must consider all 
their actions on the government, Islamic groups themselves, and parents who will later affect their learning process. The sigh of ethnicity and history of problems that occur increasingly narrow the movement of school leaders to develop Islamic education financing.

This research is very important because trying to understand the perspective of school leaders and all the teacher councils who have to respond to hard conditions where they live with various kinds of reactions, and how they practise school administration practices. This research is fairly rare, because of the leadership of the school in the middle of the school-ongoing political conflict as a forum for mobilising minority groups against the government as a different majority of religion. This study is increasingly scarce because in southern Thailand where researchers rarely study it from the leadership side of Islamic education.

\section{METHOD}

This study uses a qualitative approach (Niaz, 2009), dengan metode studi kasus (Yin, 2012) with the method of case study (Yin, 2012) focused on school leadership exploration in Pattani Province. Because the case is in the conflict area, only the criteria used in this study are easily accessed in terms of transportation and security aspects. This research was conducted with the help of our colleagues who are students from Thailand and study at one of the state universities in Malang. Information excavated when our colleague returned to his country in Thailand and based on his experience, knowing the madrasa at Pattani.

Data excavation was carried out by interview method via FGD (Focus Group Discussion) with one teacher at Madrasah Pattani and 3 students for an hour through our colleague when he returned to Thailand. The FGD is used to determine the extent of leadership in Madrasah Pattani during conflict and several other phenomena related to madrasas. After that, 
data extracting also uses supporting documents to complete information from the results of the FGD interview. As for data analysis done with several stages: data presentation, data reduction, coding, categorisation, and drawing conclusions (Ezzy, 2013; Miles \& Huberman, 1994; Sandelowski, 1995; Strauss, 1987). At this stage, data can be well interpreted about the leadership of Islamic education in Southern Thailand.

\section{FINDINGS AND DISCUSSION}

\section{Madrasah in Southern Thailand}

There are three regions in southern Thailand that are the target of this ethnic conflict, namely Pattani, Narathiwat, and Yala (Liow \& Raya, 2020). The three regions are a place where Malay Muslims as a minority group get resistance from the government in fact Buddhism. In the tension's context, Islamic educators became a battle arena that made it the main reason for banging religion and politics between the two camps.

The form of Islamic education institutions in Southern Thailand is like pesantren, a traditional Islamic education institution in Indonesia (Azra dkk., 2010; Dhofier, 1980; Raya, 2018). In this institution, Tok Guru, who resemble Kiai in Pesantren Indonesia are positioned as central figures and teach ancient books and lecture methods (Lee, 2015; Liow, 2010; Liow \& Raya, 2020). The curriculum used also uses the Shafi'i Madhhab books in a class circle called halaqah. Tok Guru usually read several temples from the ancient book then the students noted what was important.

Tensions between Muslims in Southern Thailand with the government began with the stance of the Buddhist sentiment towards Islamic boarding schools in the southern region as a container of radicalism. The allegation arose when some secret documents were found from the Thai government military unity which stated that there were 
approximately 50 Islamic education institutions in the three regions as a place to recruit and educate students for a war mission on behalf of religion (Barter \& Zatkin-Osburn, 2014; Chalk, 2001; Porath, 2011). With the disclosure of the secret document, the government then took repressive action after the tension of religious ideology strengthened in the southern region. Although repressive actions carried out by the government used an approach with policies that combined the national education system into the cottage system, but triggered tensions between Muslim groups and the Buddhist government because they were considered having changed the community's order. The second approach by imposing the use of Thailand in many ancient book-based subjects (Arabic-Malay) resulted in using Arabic and Melayu regarded as a provocative language for rebellion (Madmarn, 1990).

The government's efforts to the purpose slowly are carried out until finally issued by the provincial education development plan policy in the southern region (Liow, 2010). The policy changes the total overall education system in the southern region, such as requiring the use of bilingual (Thailand-Malay) in Islamic Education, an increase in skills and religious teacher competencies, complement school facilities, graduate career development, diploma equalisation for pesantren graduates to continue to universities, and funding for school operations. (Jory, 2013), although many pesantren in the southern region rejected the reform. The policy was increasingly disputing when the government-controlled strictly Islamic education institutions at the base level (Ibtidā'i), Medium (Mutawassiț) and thānawi through National Education Law Number 2542/19999 which divided the "fifty-fifty" religious subjects with eyes General lessons (secular), so $90 \%$ of most Muslim parents in the three regions issued their children from the Islamic school formed by the government (country) and moved to private Islamic schools because the 
policy was assessed that the policy could extinguish the values of Malay Islam in children (Brooks, 2015).

As information from our colleagues, to enter this Madrasah's access is difficult. The security checkpoint founded every kilometre made this observation quite challenging. Madrasah Pattani is on the outskirts of the city that have 3,200 students. The forerunner of Madrasah Pattani comes from a boarding school like a boarding school in Indonesia, but because of the influence of modernisation as revealed by Liow \& Raya (2020), Pattani pesantren has changed the form of a madrasa (founded in 1970) which accommodates the wishes of the Thai government and parents agar His son received religious subject and general subject. In 2015, the Madrasah in Pattani received an assessment as a madrasa with a "good quality" from the Standard Office and the Quality Assessment of National Education (ONESQA) and was categorized as a "big" madrasa level that could accommodate students of over 1000 people (Fry, 2018).

\section{Leadership mode in a Precarious Situation}

Research on school leadership in conditions and precarious situations such as conflict, violence, dispute, and war is still very rare. In this article, several studies will review the leadership of the school in the shone Zone, both in the period of conflict and post-conflict, including those that occur in South Thailand. This review serves as a comparison to the extent to which leadership effectiveness in Islamic education institutions faces difficult situations to do.

The conflict left deep wounds, especially to children where their education was forcibly taken care of by tense conditions. The situation hit by children in countries hit by wars forcing education in refugee camps with makeshift facilities, volunteer teachers, uncontrolled curriculum, and a tense situation during the learning process (Sommers, 2002). One study conducted in the Zone of the Palestinian Gaza Conflict found that 
online training for Arabic teachers to speakers in other languages where they was forced to design the design because a very sensitive immobility but graduates of universities in Gaza desperately need a decent job opportunity, as it is known that the internet network And communication mobility is blocked by the Israeli military for a prolonged conflict war that has not finished (Fassetta dkk., 2017). In the Philippine Mindanao conflict zone, college in the heart of the armed conflict area spread the place contested by the conflicting party. The Chancellor as University leaders must "rotate the brain" in the submission of effective education in conflict situations. Student Affairs is a central unit in mobilizing all campus composes to promote peace (Bernardo \& Baranovich, 2014).

In Pattani, some Muslims some minorities seek to develop Islamic education institutions in most Buddhist government hegemony. Our colleagues who are students at one of the state universities in Malang from Thailand have interviewed the Head of Madrasah Pattani at the beginning of January 2020:

"The pressure provided by the Thai government to Islamic schools here is still reasonable, even though we have to change the ideology of condensed madrasa implementing the traditional learning process. When the government applies national policies on education, all schools are required to follow the government system, as well as Madrasah Pattani, which initially only teaches Islamic subjects, the general subjects are also mandatory subjects for our madrasas such as Economics, Geography, Science, and Mathematics".

Some statements from informants from elements of Madrasah Pattani alumni who received scholarships to one of the leading universities in Malang said A1 said:

"Being a student at Pattani Islamic School is difficult, because many changes that occur because of the government's insistence on our madrasah".

A2 informant say:

"The entry of general subjects makes us happy but also interfered with worrying because our parents doubt general material to damage our 
religious understanding. As we often hear from public schools, in San A taught must throw away the principle of religion in learning general material".

It seems like this is felt by the A3 informant that we interviewed through social media:

"Our madrasah is getting a denser schedule with the entry of general material. Teachers from other religions (Buddha) sometimes also provide additional assignments to us to be done in lodging, while in the accommodation we have to take part in several activities such as recitation, taklim, and dhikr together".

Information from A1, A2, A3 is also justified by the Head of Madrasah Pattani:

"The implication of the policy, we must recruit teachers from outside the madrasa that mostly Buddhist teachers. The teacher we have in Madrasas cannot teach general subjects, because of their educational background from traditional Islamic educational institutions. When conflicts in Southern Thailand are turbulent, Islamic schools get strict supervision from the Thai military and the government always oversee every movement of our madrasa. As when learning takes place, there are spies from the military who oversee our learning process. In addition, control of curriculum evaluation was also tightened compared to public schools at a routine meeting of all school leaders in South Thailand. The government suspects our school is a place to teach ideology for rebellions against the government".

Sectarian conflicts that occur in the southern region are a dilemma condition for leaders of Islamic education institutions which are strictly supervision from the government. Besides that, the prolonged conflict between the Malay Muslim group with the government further strengthened the government's discovery of Islamic schools or madrasas. Leadership strategies are needed and speech mode or something in dealing with these conditions. The head of the Madrasah Pattani said:

"We also received some questions from sectarian groups from Malay Muslims whether they wisely accept all government policies interfere in the Madrasah system. If we reject the policy, it will strengthen the conflict gap that never ends. As a friendly society, we also have to respond to the needs of parents where their children also need general 
skills to compete with public school graduates. The entry of non-Muslim teachers at Madrasah Pattani is a middle ground for us now because of the lack of Muslim teachers in mastering the general subject, although we do in a half-forced state to compensate for this precarious condition".

Sometimes, the leadership of Islamic schools in the South Philippine Conflict area also attracted Milligan's attention, which found that profetic leadership mode was more suitable for school development in precarious conditions than traditional leadership modes that rely on kinship relationships. The school needs a figure of leaders born from religious authorities can save the school from conflict adversity with various school development strategies. Schools with integrated models are preferred by the southern Philippines community because they reach the aspirations of community needs regarding religious science, science and technology, and effective leadership that can compensate for emergencies in the conflict area (Milligan, 2010).

Post-conflict education also still leaves in-depth injuries such as in Somaliland where $80 \%$ of the population has not received proper education even though it's already independent. The solution provided is emergency education towards the revitalisation of education by integrating the non-formal system with a formal system (Bekalo dkk., 2003). Post-conflict education is a catalyst effort in helping the initial stage of the transition out of the conflict situation, there is a need for a better understanding in rebuilding peace (recovery) (Barakat dkk., 2013). There are three primary functions of the role of post-conflict education that hit the countries: First, concern for the fate of war victims of war, especially their education; Second, the education given after the conflict must be sensitive to hostility and the importance of peace; Third, education can provide an understanding that differences are a harmony that strengthens unity (Smith, 2011).

Of the various multiple modes above, it is clearly illustrated that leadership in a precarious situation requires a rapid and responsive 
response to the surrounding conditions. This is in line with the theory of Fiedler that leadership depends on the context in which he is (Fiedler, 1967), and a leader must have high respect for the institution where he works. Sometimes, school leaders have difficulty if faced with a precarious situation where he prefers to resign or survive with a weak leadership model.

\section{The Direction of Development of Madrasah Pattani}

As explained at a glance at the beginning, initially Islamic education institutions in Pattani as Islamic boarding schools, but changed forms of schools and madrasas that adopted a modern curriculum such as integrating Islamic religious subjects with general subjects (secular). This is where the vision of Madrasah Pattani also changed, where the madrasa head must adjust to the needs of the times.

"Parents want their madrasas as a comfortable and representative place to provide children with Islamic knowledge and also general sciences. At first, the parents ignored the entry of modernisation into Islamic education. Islamic religious material was sufficient to equip children's education. However, the community found their inequality that did not get general sciences in the environment and where they worked, so parents wanted the integration of general material into the Madrasah curriculum". (Head of Madrasah Pattani)

The conditions experienced by madrasas are transmissions from traditional systems that are strongly rooted in Islamic education institutions so that teachers, students, parents and communities still consider traditional systems worthy of use in modern times. But if this is left, the existence of Islamic education institutions on the development of the times can be threatened. Therefore, the head of the madrasa made a breakthrough to revitalise the Madrasah's vision under the conditions that occurred, so that the community understood the importance of a common education transform for education development.

"To strengthen the vision, the Head of the Madrasah collaborated with the Islamic Education Community in ASEAN countries as a driving force 
behind the vision. The collaboration must indeed be carried out by Geographically Thailand southern Thailand bordering Malaysia and Indonesia“. (Head of Madrasah Pattani)

Genealogical history, the relationship between the Kingdom of Thailand with the Malay Muslim community is very close (Liow \& Raya, 2020). The integration plays an important role to get support from Muslim communities in the south. The Head of Madrasah Pattani has a strong desire to build Thai Muslim communities not only limited to religious fields but other public areas. In the ASEAN community, indirectly gets inspiring how the transformation of Islamic education from traditionally becomes modern Islamic education that can bring its graduates to compete in the international market. The Head of Madrasah Pattani received a lesson from the success of Islamic boarding schools in Indonesia and Madrasas in Malaysia, which integrated the formal education system with non-formal (Steenbrink, 1974; Roff, 2004; Dhofier, 1994; Raya, 2018).

The vision is not only aspired by the Head of the Madrasah Pattani, the teachers who teach in this madrasa also want this. Ali, a teacher at the Madrasah Pattani said:

"I don't want my child to just learn religion, but aspire to want one day my child can enter a leading university abroad by studying the general science"

In a row, information from $\mathrm{A} 1, \mathrm{~A} 2$, and $\mathrm{A} 3$ said:

A1: "In Pattani, the Madrasah is an Islamic school that is synonymous with rebels, often supervised, but also diversity blends here. Buddhist teachers teach us mathematics, as well as other subjects such as the economy. There is a distinct sensation when I get general material, even though it feels boring if you continue to learn religion".

A2: "the head of the Madrasah wants us to continue to college and equivalent to public school students. It was relatively successful, the proof was that I could go to Indonesia by getting a scholarship from the government". 
A3: "My parents were initially not very interested if I went to college. In our family, the orientation of religion is the main. When I entered as a student at Madrasah Pattani, I had to learn mathematics and English. As soon as I returned home, I told the matter to parents, they were slow to get used to the Madrasah changes".

Teachers and the three Alumni of Madrasah Pattani have proven a change in orientation in the Madrasah's vision, from traditional to modern, even though the madrasa base still emphasises the ability to understand Islam. Understanding of the vision of "upstream to downstream" ranging from the head of the madrasa, parents, students, until the teachers will not be realised without the ability of the head of madrasa to articulating and aligning the similarity of madrasah vision with stakeholders.

"For these changes, we realise through regular meetings and seminars where teachers and parents discuss the future of the school and their graduates in a better direction, even though the situation and conditions are still very precarious amid vulnerable conflict". (Head of Madrasah Pattani)

The head of Madrasah Pattani said:

"Previously, our madrasah did not have enough funding and received little students, but after receiving support from the government, funding and the number of students also increased".

The composition of religious subjects at Madrasah Pattani is divided into classes twice a day (morning and evening). In the morning they have to take Islamic lessons, while in the afternoon they learn general subjects such as natural science, geography, economics, history, and others. Integrating this curriculum raises problems in students such as heavy loads to receiving the density of lessons from morning to night. The adoption of general subjects also requires madrasas to recruit Buddhist teachers to teach general subjects. This composition raises social problems among madrasah energies even though this is ordinary by some people with diversity jargon. 
"At first, we were shocked by the appearance of a female Buddhist teacher who did not wear a veil. The head of the madrasah explained this exception. Whereas we have to keep 'aurat and if it breaks our rules must be punished“. (Infoman A2)

Besides the dressing style, students are also not familiar with the learning model submitted by non-Muslim teachers:

"When the lesson begins, we always read prayers and teachers say greetings., we have to read the verses of the Qur'an before starting the lesson. When the Buddhist teacher taught, he did not say greetings and sometimes let us not pray before studying. When the lesson process, the teacher explains and students are asked to seek themselves the existing problems. Unlike Muslim teachers who have lectured more when they are lessons than looking for their problems" (Informant A1)

Although some students are shocked by the integration, they are slowly accustomed to it. But the Space Problem gap between Muslim teachers and non-Muslims still occurs, including their social relations. The steps of the madrasa head face the problem, explained in the next discussion.

\section{Building Social Cohesion: Skill of Head Madrasah}

As explained above, the recent problems faced by Madrasah Pattani with the entry of general subjects and recruiting Buddhist teachers is a challenge for the head of the Madrasah. As a leader, the head of the Madrasah outsmarted by making some activities to strengthen the relationship between Islamic religious teachers and Buddhist teachers at certain times.

"Family Day is the event that we made for a profit competition with all school residents including students, Islamic religious teachers and Buddhist teachers. They were asked to play and cooperate in this activity which was deliberately made exciting and family“. (Head of Madrasah Pattani)

The head of madrasa also gave the earliest speech that the teachers and students were asked to abandon the background of ethnic and 
cooperate in this game as if they were one family on a single roof of the house of the madrasa.

"Regards. To all the elements of the Madrasah from the teachers and students, we designed this competition for educational purposes so that children are accustomed to cooperation and to strengthen our relationship with fellow teachers. "Madrasah is superior to madrasas in collaboration, the strong madrasa of madrasah works". Congratulations on the event of this mother and students. (Madrasah's head remarks during the family day competition)

There are other things to strengthen social cohesion. Students usually kiss the hands of Muslim teachers and give respect to a slight bend to the Buddhist teacher.

"Ya, this is reflexively done by students even though in front of him a Buddhist teacher. Our students are students to respect anyone even though it is a different religion. Islam always teaches goodness even though against non-Muslims. The character is naturally formed in each student". (Head of Madrasah Pattani)

It is also said by A1 and A3:

"In the past we did not know how to behave to non-Muslim teachers, we were not used to kissing their hands. They are our teachers. Some Muslim teachers advised us to respect him properly“. (A3 informant)

"Even though they are non-Muslims, they remain our teachers. Must be respected properly". (Informant A1)

The act of respecting this teacher is proven to create solidarity between teachers and students. Even though it feels awkward, it looks beautiful diversity where they have to blend with people who are not in their circles. Social cohesion is not only built-in Madrasah Pattani but also extended to the community and different stakeholders. Although still in the conflict's atmosphere, it seems like a madrasa in Pattani doesn't want to be too long to dissolve in prolonged conflict tensions. According to the head of Madrasah Pattani:

"The madrasa with all his might thinks of what can build social cohesion. To realise this idea, every month Ramadhan some selected students are sent to lead Tarawih prayers and religious lectures. The program 
received a positive response from several people and saw the skills of students delivering religious lectures and leading prayers, many requests from the community were interested in including their children to Madrasah Pattani“.

In Madrasah Pattani there are programs called "usrah", namely teachers and students live a few days with the community and then devote themselves to cleaning the mosque, cleaning the environment, and offering to share about religion. This program is not only for Muslims but also for Buddhists and of course without sharing religion. Creating social cohesion is also done by collaborating with foreign universities. The aim is to regret religious teachers leading universities abroad with a scholarship mechanism. For example, Madrasah Pattani collaborated with the foundation of Fathullah Güllen so that the teachers received a college scholarship to Turkey. The head of Madrasah also sent teachers and graduates to various countries such as Indonesia, Malaysia, Egypt, Saudi Arabia, and others. Even 20 teachers from the Madrasah Pattani were sent to "Kampung Inggris" in Pare, Kediri, Indonesia for approximately two weeks to learn English intensively.

\section{CONCLUSION}

Some Islamic schools in Southern Thailand were under significant pressure on the conflict that occurred in the region. The issue of EthnoPolitics as a steward of tensions between Muslim minorities and the government in which Buddhism is a barrier to Islamic education institutions in the region is hampered compared to other countries such as Indonesia and Malaysia. Despite being pressured because of the continued conflict in the area, they endured and tried to display effective leadership. The results revealed that the head of Madrasah Pattani had developed a strong madrasa vision by adopting a modern curriculum and integrating it with the Islamic curriculum. The head of madrasa also recruited some Buddhist teachers to teach students of general science. 
Although this method has caused tensions and attitudes between teachers and students. But this problem can be overcome by the head of Madrasah by creating social cohesion between Muslim teachers and nonMuslim teachers with various social activities and expanding a network of cooperation with overseas universities. When the state conditions are safe, maybe this method is fairly used, but in the conflict's situation of leadership mode like this, it is very rare and difficult to apply if the conflict is due to religious and political motives.

\section{REFERENCES}

Azra, A., Afrianty, D., \& Hefner, R. W. (2010). Chapter 8. Pesantren and Madrasa: Muslim Schools and National Ideals in Indonesia. Dalam Schooling Islam (pp. 172-198). Princeton University Press. https://www.degruyter.com/document/doi/10.1515/9781400837458 $.172 / \mathrm{html}$

Barakat, S., Connolly, D., Hardman, F., \& Sundaram, V. (2013). The role of basic education in post-conflict recovery. Comparative Education, 49(2), 124-142. https://doi.org/10.1080/03050068.2012.686259

Barter, S., \& Zatkin-Osburn, I. (2014). Shrouded: Islam, War, and Holy War in Southeast Asia. Journal for the Scientific Study of Religion, 53(1), 187201. https://doi.org/10.1111/jssr.12080

Bekalo, S. A., Brophy, M., \& Welford, A. G. (2003). The development of education in post-conflict 'Somaliland.' International Journal of Educational Development, 23(4), 459-475. https://doi.org/10.1016/S0738-0593(03)00016-6

Bernardo, M. A. C., \& Baranovich, D.-L. (2014). Higher education in the heart of armed conflict: The pivotal role of student affairs. International Journal of Educational Development, 35, 78-85. https://doi.org/10.1016/j.ijedudev.2012.08.007 
Brooks, M. C. (2015). School principals in Southern Thailand: Exploring trust with community leaders during conflict. Educational Management Administration \& Leadership, 43(2), 232-252. https://doi.org/10.1177/1741143213513191

Brooks, M. C., \& Brooks, J. S. (2019). Culturally (ir)relevant school leadership: Ethno-religious conflict and school administration in the Philippines. International Journal of Leadership in Education, 22(1), 6-29. https://doi.org/10.1080/13603124.2018.1503819

Ceallaigh, T. Ó., \& Shéaghdha, A. N. (2021). Leadership and school selfevaluation in Irish-medium immersion: A roadmap for success. Educational Management Administration \& Leadership, 17411432211015218. https://doi.org/10.1177/17411432211015218

Chalk, P. (2001). Separatism and Southeast Asia: The Islamic Factor in Southern Thailand, Mindanao, and Aceh. Studies in Conflict \& Terrorism, 24(4), 241-269. https://doi.org/10.1080/10576100116748

Dhofier, Z. (1980). The Pesantren Tradition: A Study of the Role of the Kyai in the Maintenance of the Traditional Ideology of Islam in Java. https://doi.org/10.25911/5d74e363a6ded

Dhofier, Z. (1994). The Role of Pesantren in the Development of Primary Education in Indonesia. Studia Islamika, 1(2), 47-67. https://doi.org/10.15408/sdi.v1i2.857

Ezzy, D. (2013). Qualitative Analysis. Routledge.

Fassetta, G., Imperiale, M. G., Frimberger, K., Attia, M., \& Al-Masri, N. (2017). Online Teacher Training in a Context of Forced Immobility: The Case of Gaza, Palestine. European Education, 49(2-3), 133-150. https://doi.org/10.1080/10564934.2017.1315538

Fiedler, F. E. (1967). A Theory of Leadership Effectiveness. Mcgraw-Hill.

Forbes, A. D. W. (1953). Thailand's Muslim Minorities: Assimilation, Secession, or Coexistence? Asian Survey, 22(11), 1056-1073. https://doi.org/10.2307/2643979 
Fry, G. W. (2018). Religion and Educational Development in Thailand. Dalam G. W. Fry (Ed.), Education in Thailand: An Old Elephant in Search of a New Mahout (pp. 57-75). Springer. https://doi.org/10.1007/978-98110-7857-6_3

Garza, Jr, E., Drysdale, L., Gurr, D., Jacobson, S., \& Merchant, B. (2014). Leadership for school success: Lessons from effective principals. International Journal of Educational Management, 28(7), 798-811. https://doi.org/10.1108/IJEM-08-2013-0125

Gurr, D., \& Drysdale, L. (2018). System Leadership and School Leadership. Research in Educational Administration and Leadership, 3(2), 207-229. https://doi.org/10.30828/real/2018.2.4

Harish, S. P. (2006). Ethnic or Religious Cleavage? Investigating the Nature of the Conflict in Southern Thailand. Contemporary Southeast Asia, 28(1), 48-69.

Jerryson, M. (2009). Appropriating a space for violence: State Buddhism in southern Thailand. Journal of Southeast Asian Studies, 40(1), 33-57. https://doi.org/10.1017/S0022463409000034

Jory, P. (2013). Islam, Education and Reform in Southern Thailand: Tradition and Transformation. The Asia Pacific Journal of Anthropology, 14(3), 284-286. https://doi.org/10.1080/14442213.2013.787908

Lee, S. Y. (2015). Peacebuilding and Islamic Leadership in Southern Thailand. Peace Review, 27(3), 328-336. https://doi.org/10.1080/10402659.2015.1063376

Liow, J. C. (2010). Islam, Education and Reform in Southern Thailand. Dalam Islam, Education and Reform in Southern Thailand. ISEAS Publishing. https://www.degruyter.com/document/doi/10.1355/9789812309655 /html

Liow, J. C., \& Raya, M. K. F. (2020). Islamic Reformist Movement of Haji Sulong Abdul Kadir in Islamic Education Institutions in Thailand's Southern 
Border. Jurnal Pendidikan Islam, 10(2), Article 2. https://doi.org/10.38073/jpi.v10i2.346

Madmarn, H. (1990). Traditional Muslim institutions in southern Thailand: A critical study of Islamic education and Arabic influence in the'pondok'and'madrasah'systems of Pattani [PhD Thesis]. The University of Utah.

Man, W. K. C. (1985). The Malay-Muslims of Southern Thailand. Institute of Muslim Minority Affairs. Journal, 6(1), 98-112. https://doi.org/10.1080/13602008508715927

Miles, M. B., \& Huberman, A. M. (1994). Qualitative Data Analysis: An Expanded Sourcebook. SAGE.

Milligan, J. A. (2010). The Prophet and the Engineer Meet Under the Mango Tree: Leadership, Education, and Conflict in the Southern Philippines. Educational Policy, 24(1), 28-51. https://doi.org/10.1177/0895904809354069

Niaz, M. (2009). Qualitative methodology and its pitfalls in educational research. Quality \& Quantity, 43(4), 535-551. https://doi.org/10.1007/s11135-007-9136-9

Porath, N. (2011). The terrorist insurgency in the South of Thailand. Bijdragen tot de Taal-, Land- en Volkenkunde, 167(1), 130-139.

Raya, M. K. F. (2018). Sejarah Orientasi Pendidikan Islam di Indonesia (Dari Masa Kolonial Hingga Orde Baru). Jurnal Pendidikan Islam, 8(2), 228242. https://doi.org/10.38073/jpi.v8i2.202

Roff, W. R. (2004). Pondoks, Madrasahs, and the Production of Ulama in Malaysia. Studia Islamika, 11(1), Article 1. https://doi.org/10.15408/sdi.v11i1.651

Sandelowski, M. (1995). Qualitative analysis: What it is and how to begin. Research in Nursing \& Health, 18(4), 371-375. https://doi.org/10.1002/nur.4770180411 
Seyfarth, J. T. (2002). Human Resources Management for Effective Schools. Third Edition. Allyn \& Bacon/Longman Publishing, a Pearson Education Company, 1760 Gould Street, Needham Heights, MA 02494.

Smith, A. (2011). Education and Peacebuilding: From 'conflict-analysis' to 'conflict transformation'? Working Group on Peace and Development. https://pure.ulster.ac.uk/en/publications/education-andpeacebuilding-from-conflict-analysis-to-conflict-tr-3

Sommers, M. (2002). Children, Education and War: Reaching Education for All (EFA) Objectives in Countries Affected by Conflict. Conflict Prevention and Reconstruction Unit Working Paper. The World Bank, 1818 H Street, N.

Steenbrink, K. A. (1974). Pesantren, Madrasah, Sekolah: Recente Ontwikkelingen in Indonesisch Islamonderricht [PhD Thesis]. Meppel [Netherlands]: Krips Repro.

Strauss, A. L. (1987). Qualitative Analysis for Social Scientists. Cambridge University Press.

Suhrke, A. (1977). Loyalists and Separatists: The Muslims in Southern Thailand. Asian 17(3), 237-250. https://doi.org/10.2307/2643498

Wößmann, L. (2003). Schooling Resources, Educational Institutions and Student Performance: The International Evidence. Oxford Bulletin of Economics and Statistics, 65(2), 117-170. https://doi.org/10.1111/1468-0084.00045

Yin, R. K. (2012). Case study methods. Dalam APA handbook of research methods in psychology, Vol 2: Research designs: Quantitative, qualitative, neuropsychological, and biological (pp. 141-155). American Psychological Association. https://doi.org/10.1037/13620-009

Yusuf, I. (2007). The Southern Thailand Conflict and the Muslim World. Journal of Muslim Minority Affairs, 27(2), 319-339. https://doi.org/10.1080/13602000701536232 